\title{
The Case of Druze Society and its Integration in Higher Education in Israel
}

\author{
Aml Amer ${ }^{1} \&$ Nitza Davidovitch ${ }^{1}$ \\ ${ }^{1}$ Department of Education, Ariel University, Ariel, Israel \\ Correspondence: Nitza Davidovitch, Department of Education, Ariel University, Ariel, Israel, Kiriat Hamada 3, \\ Ariel, Israel. E-mail: d.nitza@ariel.ac.il
}

Received: February 23, 2020

Accepted: April 24, $2020 \quad$ Online Published: July 23, 2020

doi:10.5539/ies.v13n8p68

URL: https://doi.org/10.5539/ies.v13n8p68

\begin{abstract}
In this work, we elaborate on the changes and transformations in the Israeli education system (including higher education) from Israel's independence in 1948 to 2019. Specifically, the study places special emphasis on developments commencing in 1976 in response to the establishment of a separate administrative division for Druze and Circassian Education in the Ministry of Education, and division's impact on the rate of youngsters who earn matriculation certificates and the number of Druze students attending higher education institutions. of the study analyzes the administrative separation of Druze education in the education system and its effect on the integration of Druze youngsters in higher education in Israel.

The current study contributes to our understanding of the development of the Druze education system as a distinct unit in the Israeli Ministry of Education. The findings of this study and its conclusions will contribute to policymakers in the Ministry of Education in general, and policymakers concerning Druze education specifically, seeking to improve educational achievements and apply the insights of the current study to other minority groups to which higher education has become increasingly accessible in recent years.
\end{abstract}

Keywords: higher education, cultural perspective, learning, Druze society, integration

\section{Introduction}

\subsection{The Education System in Israel}

Israel's current (2020) population is 8.9 million, comprising 6.6 million Jews (74.3\%), 1.878 Arabs (20.9\%) and 426,000 (4.8\%) non-Arab Christians, members of other religions, and atheists. At end 2018, the Druze population in Israel was 143,000 or $1.6 \%$ of the country's total population (Central Bureau of Statistics, 2019).

In the 2017/18 school year, a total of 2,615,000 students were enrolled in the education system from kindergarten to university level, representing an increase of 774,000 students since 2000 . Approximately $76 \%$ of the students study in the Jewish education system, while $24 \%$ study in the Arab education system. These statistics for the Arab education system include students from the Arab, Druze, Bedouin, and Circassian sectors (Central Bureau of Statistics, 2019).

Based on Central Bureau of Education figures (2016a, 2016b) and assuming 2\% annual growth, in 2018 a total of 1.72 million pupils were enrolled in grades K-12, of which 1.27 million Jewish pupils and 0.45 non-Jewish pupils: 322,000 Arabs, 94,000 Bedouins, 544 Circassians, and 34,000 Druze pupils. Druze pupils account for 1.9\% of the pupils in the country's education system. (Note 1)

Between 2000 and 2018, the number of pupils in the Jewish and Arab education systems increased by $38 \%$ and $62 \%$, respectively. However, the changes in these systems varied over time: Between 2000 and 2005 the increase in the number of students in the Jewish education system was much smaller than in the Arab education system (3.7\% and 28.0\%, respectively), yet between 2005 and 2010 the increase in the number of students in the Jewish system doubled (7\%) while the number of students in the Arab education system decreased by $14.0 \%$. This trend reversed again since 2010, and between 2010 and 2018, the rate of increase in the number of students in the Arab education system was much higher than in the Jewish education system (24.2\% and $12.0 \%$, respectively) (Central Bureau of Statistics, 2019).

The Jewish education system includes several educational sectors including the public sector, the 
national-religious sector, and the independent Haredi (ultra-orthodox) sectors. The Arab system includes the Druze, the Circassian, and Bedouin sectors, yet each of which constitutes a separately administrated unit. All the sectors (with the exception of Haredi education) are subject to the curricular and administrative authority of the Ministry of Education under the Public Education Law (1953), which allows parents to choose an educational sector that matches their worldview.

The education system in Israel experienced the following important milestones in its development:

(1) The uniform education system from 1948 to approval of the conclusions of the Fromkin Committee in 1950;

(2) Integration in education, since 1968;

(3) Conclusions of the Ben-Peretz Committee in 2001 to modify the structure of the matriculation exams;

(4) Conclusions of the Dovrat Committee in 2003, following by the educational reform ('New Horizon') in 2007 (Viner Levy, 2004).

Since 2007, the Israeli education system has been operating under the New Horizon and Courage to Change reforms, which significantly increased both teachers' salaries and their working hours (in elementary and secondary education, teachers now work 36 rather than 30 weekly hours, and 36 rather than 24 hours, respectively). These reforms were related to international standards that the education system in Israel was compelled to meet (Education at a Glance, 2007).

Furthermore, Israel's higher education system underwent a revolutionary transformation beginning in the 1990s, which led to a sharp rise in the number of students in colleges and universities, the establishment of new accredited academic institutions, legislative changes, regulatory and policy changes, and changes in the general policy on the goals and missions of academic institutions (Falah, 2000).

\subsection{The Druze Community in Israel}

The beginning of the Druze religion can be traced to eleventh century Egypt, and the principles of the religion focus on seven precepts (truthfulness in speech, mutual protection of the brethren, renunciation of idol worship, avoidance of evil deeds, confession of God's unity, submission to God's divine will at all times, absolute resignation to God's secret and observed acts; Falah, 2000).

The Druze in Israel live in conservative rural society, their lifestyle is based on religion and led by their religious leaders. Druze society is divided into two camps: religious and secular Druze. The Druze religion is secret and only orthodox Druze are initiated into its tenets (Abu Azaladin, 1990). The structure of Druze society is a source of strength for its members. The family is at the center of society, followed by the clan and the community. The Druze believe that all community members are linked by a blood relationship and share a common destiny: The identification among community members is strong as is their discipline and obedience to their leaders, especially in the past. These features are reinforced by their religious beliefs (Ben-Dor, 1995).

In traditional Druze society, identification with one's clan and family was especially strong. When society was agricultural and patriarchal, and all community members worked the land, revenues were channeled to the head of the clan. As a result of the changes that the Druze villages experiences, social and familial solidary has weakened considerably as individualism strengthened (Dana, 1998). In the past, the Druze were the least educated group in Israel and the community's intelligentsia, which has the potential to lead modernization, was very small, as was the number of economic entrepreneurs representing new capitalism (Ben-Dor, 1995).

The Druze community it aware of the need to adapt to contemporary changes, but like other traditional societies is concerned about the implications of such adaptation. Modernization demands a revolutionary change in the traditional village community and a willingness to adjust to urbanization. The roles and attitudes of the younger generation also tend to change as a result (Salah, 1989).

The Druze community underwent significant changes in employment and economic activity in the transition from a traditional, conservative agricultural society to a technologically oriented, industrialized society. Today, only $10 \%$ of the communities are engaged in agriculture, compared with $90 \%$ employed in various industries and public services (Abu-Rokan, 1966).

All Druze villages have a similar social hierarchy: community, clan, household, and individual. Religious beliefs, solidarity, social ties, familial affiliation and a sense of belonging to the community are the elements that solidify this collectivist, particularist social structure in Druze society (Dana, 1998). Like Arab society, the Druze typically live in a patriarchal structure, with additional features rooted in their tradition and religious beliefs. A father's absolute control of the members of his extended family derives from Mediterranean Arab culture, in which the interests of the individual are subsumed under the interests of the collective. Despite Western influences on Druze 
society, the latter retains the features of a collectivist society, and especially reflected in honor and respect to one's parents and the family's central role in the life of the individual.

Certain traditional patterns of thought and culture affect the decisions made by young members of the Druze community and help them control their life. Druze have a strong sense of support and belonging to an extended family, and one's strong continuous connection to one's family is both beneficial yet imposes on one an endless circle of obligations. Young Druze are compelled to deal with family-related stress and family involvement and interference in one's personal life, and demands for conformity, while following their own personal aspirations (Scrimin, Moscardino, \& Natour, 2014).

In Israel, the Druze is one of the number of groups that comprise Israel's pluralistic society. They enjoy liberties, demand equality, follow their own lifestyle, and are protected by their special status among all the non-Jewish minorities in Israel. They have social power and proudly consider themselves an aggressive tribe within and on behalf of the state. The alliance between the Jews and the Druze, in contrast to the relationship between the country's Jews and Arabs, highlights the two groups' common interests and common destiny. The blood alliance in the area of national defense is a symbol of the special relationship between the Jewish and Druze nations. This alliance began at the beginning of the previous century, concurrently with the first waves of Jewish immigration. During the Arab riots in 1936-1939, the Druze either adopted a neutral stance or supported the Jews. The small Druze community of several thousand sought to establish good relationships with the Jews as a means of protecting themselves against the intimidating Arab population (Faraj, 2002). Representatives of the Jewish and Druze communities met in Shfaram, Yarka, Dalyat al-Carmel, and Pki' in to discuss plans to protect both Jewish and Druze villages, and the ties between the two sectors grew closer following the Muslim attacks against the Druze in Usefiya, especially after- Druze leaders who advocated good relations with the Jews became targets of assassination.

Due to this historical relationship, the Druze community was granted cultural autonomy when Israel became an independent state. The government took steps to promote the institutional particularity of the Druze community in contrast to its policy toward the general Arab population. This recognition paved the way to the emphasis on the community's unique nature and separation from all other minorities in the country (Dana, 1998). A long series of actions reflected this attitude: recognition of the Druze as a separate religious community distinct from Muslims (1956), mandatory conscription in the IDF (1957), establishment of the Druze religious council (1961) and religious courts (1962), and the provision of government services through the government departments for the general (rather than minority) population (1975).

Prime Minister David Ben Gurion proposed that Druze soldiers could serve in all IDF units. Ben Gurion, together with the following prime ministers Yitzhak Ben Zvi and Moshe Sharett, as well as leaders of the Labor Movement and other government officials, supported preferential government treatment of the local Druze councils and development of the community's villages. Major state institutions including the Jewish National Fund and the Prison Service were open to employment for Druze community members. The state recognized the tomb of Nebi Su'eib at Karnei Hitim as a sacred site under the auspices of the Druze community, rejected the Muslim demand for control of the site. In general, the Druze community demonstrates a trend of cultural differentiation together with increasing integration in Israel.

Upon Israel's independence, the Druze sect was identified as belonging to the Arab sector for educational purposes, and one of the prominent results of that identification was the inclusion of Druze school children in the Arab education system. Until 1976, the education system in Druze localities was part of the Arab education system, and like the Arab system it too suffered from poor physical conditions and a low standard of education. However, in the 1960s and 1970s, a new zeitgeist affected the Druze community leaders, who were concerned by a lack of cultivation of the educational roots of the youngsters, among other things, which led to assimilation into the Arab sector and growing alienation from their own religion and heritage. In response to these concerns, demands to increase community consciousness emerged.

In the 1970s, Druze leaders took action to disconnect from the Arab school system by advocating the establishment of a separate system (Falah, 2000), to be known as the Division of Druze Education, to allow them to add unique contents to the curriculum, such as the history of the Druze community (State Archive, 1.1.84-3.6.85, p. 335). The Ministry of Education and Culture was the first government ministry that acted on the ensuing official governmental decision, and removed Druze education from the administrative supervision of the Department of Education and Culture for Arabs, and in 1976 established the Committee for Education and Culture for Druze to handle the pedagogical and ethical aspects of Druze education (the Committee also handled education in the small Circassian community) and develop curricula that would reflect special contents relevant to the Druze community. 
The independence of Druze education was thus establishment (Falah, 2000).

The Druze education system was adapted to the contents of the community. New textbooks were written to teach the unique contents and aspects of Druze heritage; hundreds of Druze teachers were trained; in-service teacher training courses were conducted; a large number of new classrooms, libraries, and gymnasiums were constructed; vocational and technological education was increased; and steps were taken to increase the very low number of Druze community members who continued to higher education. The new education system defined its goal to developed a Druze-Israeli consciousness and identity among the Druze school children, designed to promote their identification with the state and its symbols by emphasizing the commonalities between the Druze and the Jews, on the one hand, and by distancing Druze school children from their Arab identity. To implement this policy and achieve these goals, Arab teachers in Druze schools were replaced by Druze teachers, new curricula were developed to replace existing contents, and a new subject, Druze Heritage, was introduced, and was designed to serve as a means for creating a new, pro-Jewish and prof-Israeli Druze identity.

Within five years, the Committee had set up an independent education system in terms of pedagogy, content, physical structures, and learning aids related to various areas of education and culture (Abas, 2004). The Druze education system assumed the over-arching goals of shaping graduates who were able to integrate into Israeli society, have a sense of love and belonging toward the country, be loyal citizens and partners in the country's development and defense, and connected to the Druze community (Peled, 1976). The Druze education system strives to create a dual formative effect on Druze youngsters by fostering their connection to their heritage and cultivating their connection and loyalty to the state of Israel.

Since this separation, educational attainment in the Druze sector has increased, both in terms of the number of children in school and in the ratio of matriculation certificates earned by boys and girls. Ministry of Education statistics indicate that in the 2014/2015 school year, a total of 41,266 Druze pupils were enrolled in the education system in Israel: 32,754 in elementary, junior and high schools, and 8,512 in kindergartens. That year, the Druze education system comprised 319 kindergartens, 51 elementary schools, 23 junior high schools, and 25 high schools. The change in the number of school children in Druze schools in Israel over time. There is a general significant increase over time, which corresponds to the increase in the Jewish education system (Weisbleu, 2016).

Today, the ratio of matriculation certificates earned in the Druze population is one of the highest of all sectors, exceeding ratios in both the Arab sector and the Bedouin sector (Weisbleu, 2016).

The average ratio of matriculation certificates earned by twelfth-graders in high school increased in the entire population and in the following education systems: Negev Bedouin, Druze, Arab, Jewish. For some groups, the increase is steeper while for others it is more moderate. In the 2011/2012 school year, $62.8 \%$ of all Druze twelfth-graders earned a matriculation certificate, a ratio only $3 \%$ lower than the ratio in the Jewish population. Between 2011/2012 and 2016/2017, there was a sharp 25\% increase in this ratio continued in the Druze population. In the 2016/2017 school year, $79.1 \%$ of all twelfth-graders in the Druze education system earned a matriculation certificate, surpassing the ratio in the Jewish education system by $10 \%$.

The proportion of twelfth-graders who sit for matriculation exams of all twelfth-graders. In 2016/2017, close to $91 \%$ of all twelfth-graders in the country sat for matriculation exams. This ratio remained steady over the previous decade. The achievements of Druze school children are very impressive: Close to $98 \%$ sat for their matriculation exams, and $75 \%$ earned a matriculation certificate, as shown in Table 1.

Table 1. Twelfth grade Druze pupils who sat for matriculation exams, earned matriculation certificate, and met minimum university admission requirements

\begin{tabular}{ccccccc}
\hline & \multicolumn{2}{c}{2012} & & 2013 & & 2014 \\
\hline & $\begin{array}{c}\text { No. of } \\
\text { pupils }\end{array}$ & $\begin{array}{c}\% \text { in a technology } \\
\text { track }\end{array}$ & $\begin{array}{c}\text { No. of } \\
\text { pupils }\end{array}$ & $\begin{array}{c}\text { \% in a technology } \\
\text { track }\end{array}$ & $\begin{array}{c}\text { No. of } \\
\text { pupils }\end{array}$ & $\begin{array}{c}\% \text { in a technology } \\
\text { track }\end{array}$ \\
\hline $\begin{array}{c}\text { Twelfth grade pupils } \\
\text { Of whom, sat for matriculation } \\
\text { exams }\end{array}$ & 2,243 & $44.2 \%$ & 2,385 & $47.7 \%$ & 2,271 & $56.4 \%$ \\
$\begin{array}{c}\text { Of whom, earned a matriculation } \\
\text { certificate }\end{array}$ & 2,157 & $43.5 \%$ & 2,305 & $47.8 \%$ & 2,221 & $56.5 \%$ \\
$\begin{array}{c}\text { Of whom, meet university } \\
\text { admission requirements }\end{array}$ & 1,410 & $37.5 \%$ & 1,636 & $47.4 \%$ & 1,661 & $58.6 \%$ \\
\hline
\end{tabular}

Note. https://fs.knesset.gov.il/\%5C20\%5CCommittees\%5C20_cs_bk_323517.pdf 
Table 1 shows the considerable increase in the number and percentage of technology track graduates of all twelfth grade Druze pupils, and in those who earned a matriculation certificate upon graduation. A historical and comparative study of matriculation certificates earned in the Druze education system over time, compared to other population groups, shows that all age groups in Druze education increased considerably in the past decade, and in the 2013/2014 school year, the ratio of matriculation certificates earned exceeded the ratio in the Jewish education system. However, the ratio of high school graduates who meet minimum university admission requirements has remained stable for a decade, with some fluctuations in both directions, and is lower than the ratio of high school graduates in the Jewish education system who meets these requirements.

These statistics indicate that the educational achievements and ratio of matriculation certificates earned in the Druze community are exceptional and impressive. At the rate at which the Druze community is progressing, the matriculation rate in this community will soon be equal to the matriculation rate in the Jewish majority. Already today, $90 \%$ of all 18 -year-olds are enrolled in high school (compared to $98 \%$ in the Jewish sector) and the Druze community is closer to the achievements of the Jewish sector in all measures of educational achievement than is the Arab sector.

The story of the Druze population in Israel is one of great accolades from the Jewish population and establishment, on the Druze community's attitude and loyalty to the state, yet on the other hand, the community's leaders have serious complaints of a discriminatory and prejudicial attitude of the government, which is unjustified in view of the community's loyalty to the state. Complaints also concern the education system in Druze localities.

\subsection{The Arab Education System in Israel}

In Israel, sectors significantly differ in the ratio of matriculation certificate earners, a figure that directly affects students' chances of admission in higher education systems. The most prominent difference is between the Jewish and the Arab sectors, which also significantly differ in socio-economic status. In the 1950s, the socio-economic differences between the two sectors increased due to discriminatory policies toward Arabs in the areas of land, infrastructure development, and economic planning and development. The military administration, which also imposed restrictions on mobility and other activities on the Arab population, was terminated only in 1966. The exclusionary and discriminatory policy did not change significantly, as noted by the 2002 Report of the State Comptroller and Ombudsman and the 2003 Orr Committee Report. Exclusion and discrimination are especially prominent in the allocation of state lands, objections to changes in jurisdiction boundaries, policies on unrecognized villages, and lack of development of physical and social infrastructure. Inequality is also reflected in the lower allocation of resources for education and for assisting traditional systems to adapt to the challenges of the present and future (Gabizon, 1998). Although these differences decreased over time, they still remain significant.

As a result, the Arab minority is mainly of lower socio-economic status compared to the Jewish population, which is mainly middle-class. Low socio-economic status constitutes a lower starting point both in the allocation of and competition over resources in Israeli society (Smooha, 2004).

The problems of Arab society are not only the result of the longstanding policy of discrimination and neglect since independence. Rural Arab society underwent socio-economic changes that prompted a process of proletarianization without industrialization that exacerbated internal economic, sectarian, and religious divisions. The Arab population is at the bottom of the socio-economic pyramid with poverty rates almost double those in the Jewish population. Educational achievements in the Arab sector, one of the most significant instruments of social mobility, lag far behind achievements of the Jewish population (Alhaj, 1996).

The research literature on Arab education in Israel points to differences in educational inputs and outputs between Jewish and Arab education systems (Arar \& Haj Yehi, 2007). Studies show that the issue of Arab education is low on the social and national agenda, and also indicates that budgets and infrastructure development are lower and that both systems have a different conception of the narrative on which the Arab education system is grounded.

Most governmental or ministerial committees on the development of academic teaching institutions in Israel addressed the Jewish and Arab education systems both and adopted a universalist approach that disregarded both the differences resulting from the inequality between the two sectors and their different ethnic identity. Against this background, the Ariav Committee Report in 2006 heralded favorable news for the Arab sector, as it largely cancelled its dependence on the public-Jewish education system and examined Arab schools according to more egalitarian criteria. In general, this Report recommended greater freedom to Arab colleges in devising ways to emphasize their cultural uniqueness by developing curricula that focus on the social needs of the Arab minority.

The differences between the Jewish and Arab sectors are reflected in the differences in the ratio of matriculation certificate earners and in the numbers of students in colleges and universities. The researchers concur with Blass 
(2011), an education researcher at the Taub Institute, who claims that matriculation statistics reflect all the biases in Israeli society and the significant differences between the groups that comprise Israeli society. A matriculation certificate is an admission ticket to academic studies, which lead to high-quality employment. Youngsters who fail to matriculate will be unable to study in academic institutions, a fact that significantly diminishes their chances for success in life. The competencies that the education system teaches pupils are those that determine the pupils' chances of studying in academic institutions. Education is a foundation for equal opportunities to which all children in Israel are entitled, yet statistics show that the Israeli education system is unable to create equal opportunities for its weaker high school graduates.

\subsection{Educational Autonomy in Israel}

One of the major concerns of the education system in Israel since its establishment has been educational autonomy for those population sects that differ significantly from the secular Jewish population, especially the Arab population. In order to maintain the unique features of its cultural identity, a group must have autonomy. The right to influence educational contents is related to the right to maintain collective identity.

The extent of a minority's cultural freedom to select its own identities and determine the values and norms that it wishes to education its future generations is principled issue. This is the case for the ethno-national indigenous Arab-Palestinian minority in Israel and its right to self-administration in the field of education, that is, its right to educational autonomy (Rabin, 2002). Addressing the specific fundamental right of an indigenous minority to affect the contents of its education, Alhaj (1996) noted that right is related mainly to the debate over the rights of the Arab sector, as a minority, to maintain educational autonomy. The question is, to what extent does the Arab sector in Israel, as a minority; enjoy a right to influence its education. Arab education in Israel is administered largely by Jewish state officials and decision makers. The powers of the Arab local governments and Arab school principals are mainly technical, while the substantive decisions are made by the Ministry of Education (Alhaj, 1996). The fact that Arabs have no impact on Jewish-Hebrew education is an axiom, yet it is nonetheless astonishing that Arabs play an extremely small role in managing their own education. With all respects related to curricula, Jews control the Arab education system. For many years, the committees that formulated the curricula and goals for the Arab schools were populated primarily by Jews (Alhaj, 1996).

It has been argued, mainly by the Arab-Muslim population, that the Jewish education system's overall control of the Arab education system prevents the Arab population from defining its own educational goals, usurps its right to shape and design its education system according to its collective interests, and undermines any significant involvement of Arab-Palestinian educators in the decision making process regarding the allocation of public resources to schools and regarding the contents of educational materials designed for Arab pupils (Saban, 2002).

Teaching in the Arab language remains the main indicator of a separate education system, but the language of instruction does not reflect the contents of education. We can compare the large investment in motivation and study hours in Hebrew instruction in Jewish schools, which is a function of the worldview that considers language a primary element in the national revival of the Jewish people, in reinforcement of national identity and national self-image, with Arab language instruction in Arab schools, which is limited to language skills and not more (Peled, 2006).

Cultural and educational autonomy to the Arab education system has been proposed in the past, in the form of two options. The first is to cultural autonomy, which mainly concerns culture, education, religion, language, and communications. Cultural autonomy is personal autonomy that applies to individuals who belong to a specific minority group, irrespective of their place of residence; In this respect it differs from territorial autonomy that applies to a specific territory and includes everyone residing in that territory (Smooha, 1999).

The fact that the Arab citizens of Israel are geographically dispersed throughout the country (mainly in the Galilee, the Triangle, the Negev and cities in the Plains), the relevant discourse for the Arab-Palestinian minority in Israel is non-territorial cultural autonomy (Klein, 1987), which implies statutory cultural autonomy (regulated by law), under which an autonomous council is elected by the members of the relevant minority group. The second option is a more limited version of autonomy for the Arab-Palestinian minority, limited to education, without the involvement of an autonomous Arab council.

\subsection{The Druze in Israel's Higher Education System}

In recent decades, various aspects of the higher education system in Israel have undergone radical change: a sharp rise in the number of students, the establishment of new accredited institutions, legislative changes, regulatory changes and changes in the general policy regarding the goals of academic institutions. In the 1990s, Israel's higher education system was characterized by a very significant and rapid average annual growth of $81 \%$ in the number of 
students. This created a radical change that sparked heated public debates. In view of the limited resources available for the academic system, numerous models of academic institutions developed, including extensions of foreign universities, and institutions that were established with no public intervention. In response, the government approved the establishment of new academic colleges to serve the growing demand for higher education (Davidovitch, 2015). Tables 2-4 present the percentage of Druze students in higher education, by institution type (universities, academic colleges, and academic teaching colleges). Table 2 presents the percentage of Druze students of all university students, Table 3 presents the percentage of Druze students in academic colleges, and Table 4 presents the percentage of Druze students of all academic teaching college students.

Table 2. Percentage of Druze students of all university students

\begin{tabular}{ccccccccc}
\hline & 2010 & 2011 & 2012 & 2013 & 2014 & 2015 & 2016 & 2017 \\
\hline Total students & 123,965 & 125,059 & 125,546 & 124,957 & 134,186 & 132,064 & 129,823 & 128,182 \\
Druze students & 1,736 & 1,902 & 1,969 & 1,915 & 1,889 & 1,908 & 1,898 & 1,971 \\
$\begin{array}{c}\text { Percentage of Druze } \\
\text { students }\end{array}$ & $1.4 \%$ & $1.5 \%$ & $1.6 \%$ & $1.5 \%$ & $1.4 \%$ & $1.4 \%$ & $1.5 \%$ & $1.5 \%$ \\
\hline
\end{tabular}

Note. https://fs.knesset.gov.il/\%5C20\%5CCommittees\%5C20_cs_bk_323517.pdf

Table 3 presents the percentage of Druze students of all academic college students.

Table 3. Percentage of Druze students of all academic college students

\begin{tabular}{cccccccc}
\hline & 2010 & 2011 & 2012 & 2013 & 2014 & 2015 & 2016 \\
\hline Total students & 83,371 & 87,409 & 91,665 & 94,515 & 96,245 & 96,328 & 89,944 \\
Druze students & 584 & 612 & 733 & 851 & 1,037 & 1,285 & 1,529 \\
Percentage of Druze students & $0.7 \%$ & $0.7 \%$ & $0.8 \%$ & $0.9 \%$ & $1.1 \%$ & $1.3 \%$ & $1.7 \%$ \\
\hline
\end{tabular}

Note. https://fs.knesset.gov.il/\%5C20\%5CCommittees\%5C20_cs_bk_323517.pdf

Table 4. Percentage of Druze students of all academic teaching college students

\begin{tabular}{cccccccc}
\hline & 2010 & 2011 & 2012 & 2013 & 2014 & 2015 & 2016 \\
\hline Total students & 20,099 & 20,826 & 21,952 & 22,295 & 23,812 & 24,578 & 25,062 \\
Druze students & 281 & 354 & 351 & 424 & 574 & 564 & 627 \\
Percentage of Druze students & $1.4 \%$ & $1.7 \%$ & $1.6 \%$ & $1.9 \%$ & $2.4 \%$ & $2.3 \%$ & $2.5 \%$ \\
\hline
\end{tabular}

Note. https://fs.knesset.gov.il/\%5C20\%5CCommittees\%5C20_cs_bk_323517.pdf

The most significant change occurred when the Knesset passed Amendment 10 to the Council of Higher Education Law 1995. The new amendment equalized academic degrees awarded by colleges to those awarded by universities. This new policy created access to higher education institutions for the masses. In the 2016 school year, $66 \%$ of all BA students studied in some type of college. Since the 1990, the higher education system in Israel tripled in size (in 2016 the total number of students in higher education in Israel, including the Open University, was 308,355 . In the academic colleges, the study body increased by more than 20 times in that period. Today, the colleges constitute the dominant type of institution in the higher education system, especially in the country's geographically peripheral areas where all the Druze villages are concentrated. As a result, the system's radical transformation also affected the Druze community and led to a significant increase in the demand for higher education among members of the community.

The significant rise in the number of Druze students occurred after the Druze education system separated from the Arab education system. In the late 1970s, only several dozens of Druze students were enrolled in Israel's higher education institutions, while in 2017/2018, 4,900 Druze students were enrolled in the country's higher education institutions, excluding the Open University, reflecting a 2.5\% increase from the previous year (Central Bureau of Statistics, 2019). Table 5 presents the changes in the number of Druze students in higher education between 2009 and 2015. 
Table 5. Changes in the number of Druze students in higher education, 2009-2015

\begin{tabular}{cccccc}
\hline & $\begin{array}{c}\text { Total no. of Druze } \\
\text { students }\end{array}$ & $\begin{array}{c}\text { Enrolled in } \\
\text { universities }\end{array}$ & $\begin{array}{c}\text { Enrolled in the Open } \\
\text { University }\end{array}$ & $\begin{array}{c}\text { Enrolled in academic } \\
\text { colleges }\end{array}$ & $\begin{array}{c}\text { Enrolled in teacher } \\
\text { training colleges }\end{array}$ \\
\hline $2009-2010$ & 1,700 & 707 & 248 & 503 & 242 \\
$2013-2014$ & 4,189 & 1,817 & 556 & 1,094 & 722 \\
$2014-2015$ & 4,606 & 1,908 & 673 & 1,358 & 692 \\
\hline
\end{tabular}

Note. https://fs.knesset.gov.il/\%5C20\%5CCommittees\%5C20_cs_bk_323517.pdf

According to the 2014 figures of the Central Bureau of Statistics, Druze students comprised 1.5\% of all students enrolled in universities in Israel that year. This percentage was highest in Haifa University (5.7\%) followed by the Technion (1.9\%). The lowest percentage was recorded in Ben Gurion University of the Negev $(0.2 \%)$. Of all students enrolled in academic colleges, Druze students comprised $1.8 \%$ although percentages varied significantly across the colleges, mainly by geographic location. Druze students accounted for a relatively high percentage of the student body in academic colleges in the north of Israel: $14.4 \%, 13.3 \%, 7.6 \%$, and $5.9 \%$ in the Academic College of Zfat, the Academic Colleges of Western Galilee, the Ort Brauda Academic College of Engineering, and the Academic College of Kineret in the Jordan Valley, respectively. In contrast, in 13 academic colleges located in the center and south of Israel, Druze students accounted for $0.2 \%$ of the student body. In academic teacher training colleges, Druze students accounted for $2 \%$ of the student body. Figure 1 presents the development of enrollment of Druze students in higher education between 2010 and 2017.

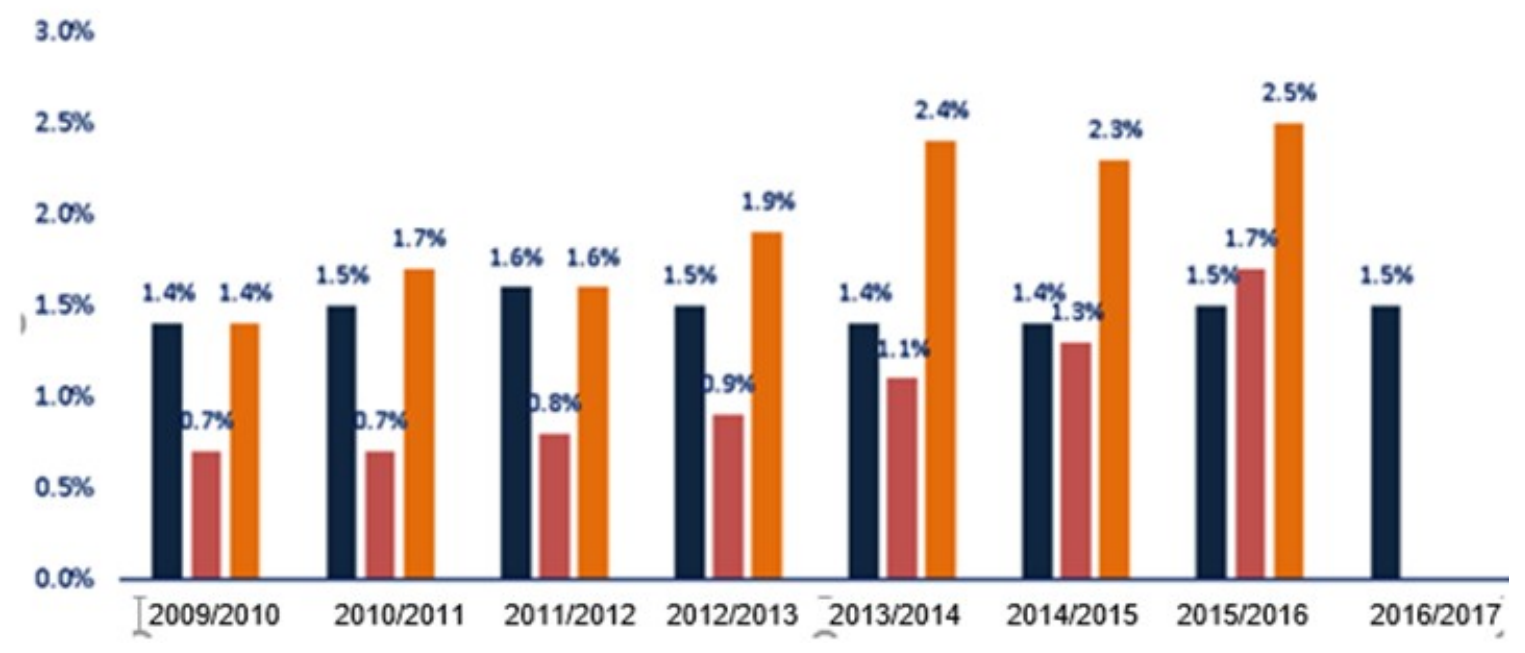

Figure 1. Percentage of Druze students in higher education between 2010 and 2017

With respect to disciplines of study, specific disciplines were more popular among Druze students than among all BA students in general (liberal arts, languages, literature, regional studies, education and teacher's education, biology and biology-related subjects), while other disciplines were less popular (e.g., agriculture, physics, business administration and management, and law).

In terms of the gender division of Druze students, women accounted for a higher percentage of Druze students than their percentage among all BA students $(64.0 \%$ and $57.5 \%$, respectively) and graduate students $(64.0 \%$ and $60.8 \%$, respectively). Furthermore, between 2009/2010 and 2013/2014, the number of bachelor degrees awarded to Druze students increased significantly from 580 to 776 . In this period, the degrees awarded to Druze students in universities increased by more than $25 \%$, from 399 to 502 , and more than doubled with respect to degrees awarded by academic colleges (from 81 to 161). In total, in this period, the number of degrees awarded to Druze students increased from 480 in 2010 to 538 in 2014, with a dramatic increase in the number of graduate degrees awarded (75 in 2010 and 217 in 2014; Central Bureau of Statistics, 2016a). Figure 2 presents the percentage of Druze students compared to the national average. 


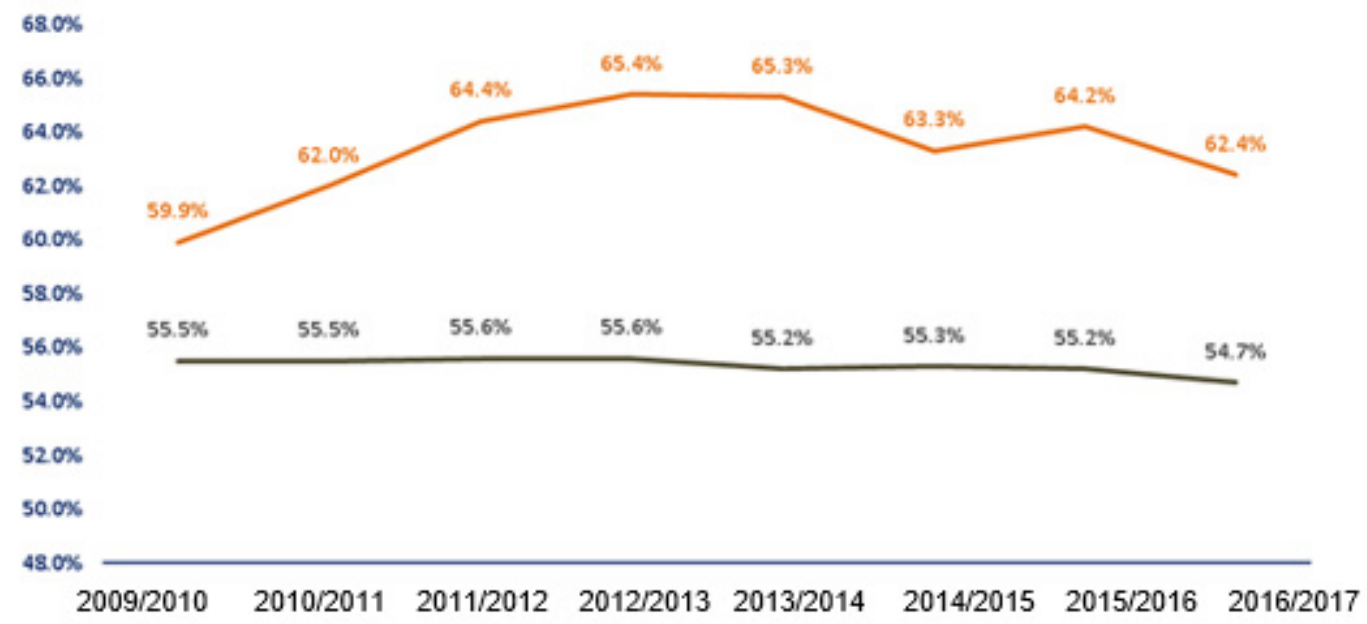

Figure 2. Percentage of Druze students compared to the national average

These and additional data will be used as the dataset for the current study to explore the changes that affected the Druze community and led to the sharp rise in enrollment in higher education. These changes invite a broader debate on the social and cultural changes experienced by the Druze community in Israel in recent years. One debate, for example, concerns Druze women's entry into the higher education system. It is well known that until the late twentieth century, the Druze community prevented women from acquiring an academic education for reasons related to tradition and modesty (Falah, 1991), and enrollment in academic institutions involved the risk of a boycott by the community (Viner Levy, 2004). Nonetheless, and despite the toll of double discrimination, both as members of a minority in Israel, and as women in a patriarchal society, several Druze women broke out of these constraints and elected to study in a university rather than assume a traditional role. This research will discuss the patterns of study and education and the traditional gender roles in the Druze community that had a significant effect on the increase in the number of Druze students in higher education, especially in the past two decades.

\section{Summary and Discussion}

The educational and other achievements of the Druze community, in terms of ratio of matriculation certificates earned and number of students enrolled in higher education institutions, are exceptional and impressive, especially the achievements related to matriculation. The question arises as to the resources that aided Druze youngsters in overcoming the economic and budgetary constraints to which they are subject and achieving such high ratios of matriculation certificates earned, where matriculation certificates are a ticket of admission to higher education. That is to say, can the exceptional achievements of Druze students be attributed to the separation between the Druze and the Arab education systems or do they represent the outcome of an internal socio-cultural transformation in Druze society?

The review of literature indicates that matriculation is a ticket of admission to higher education. The skills that high school students are taught significant affect their chances of admission to institutions of higher education, which constitute a foundation for equal opportunities to which all children in Israel are entitled. Proper, effective preparation affects students' achievements on matriculation exams and their advancement to higher education. The more appropriate preparation conducted by high schools, the greater chances students have to acquire an academic education. We believe that proper preparation has a strong impact on students' sense of preparedness and efficacy and on the integration of Druze high school students poised at the entrance to the academic world.

\section{Contribution of the Research}

The current study will contribute to our understanding of the development of the Druze education system as a separate administrative unit in the Ministry of Education in Israel. The study may contribute to policy makers in the field of education in decision making involving education in general, and specifically decisions involving the Druze education system, toward improving educational achievements in other minority groups that are 
experienced increased accessibility of and demand for higher education. This study also has implications for educational policymakers worldwide who are deliberating over demands of minority groups for separate education systems.

\section{References}

Abas, R. (2004). Culture of Druze schools compared with Arab schools, an ethnographic cash study (Master's thesis, School of Education, Bar Ilan University).

Abu Azaladin, N. (1990). Aldruz fi altaarich [The Druze in history]. Beirut: Dar Alalam Lalmalayan.

Abu-Rokan, G. (1966). Alnabaa wa-altarbiya aldiniya. Majlat Alahbar Aldruziya, 3(3/4), 8-12.

Alhaj, M. (1996). Education among Arabs in Israel - Control and social change. Jerusalem: Magnes.

Arar, H., \& Hak Yehi, K. (2007). Arab students from Israel in Jordanian universities: Issues and dilemmas. In H. Arar, \& K. Haj Yehi (Eds.), Academics and higher education among the Arabs in Israel - Issues and dilemmas (pp. 223-259). Tel Aviv: Ramot.

Ben-Dor, G. (1995). The Druze Sector in Israel in the Late 1990s. In H. Hershkovitz, \& M. Emanuel (Eds.), The Druze sector toward the twenty-first century. Jerusalem: Jerusalem Center for Public Affairs.

Ben-Peretz, M. (2001). Teacher training in Israel in changing times: Report of the Committee for the Examination of Teacher Training in Israel. Jerusalem: Ministry of Education.

Blass, N. (2011). Have the achievement of the education system in Israel worsened in recent years? Policy paper no. 2011.01 (pp. 1-51). Jerusalem: Taub Center.

Central Bureau of Statistics. (2014).

Central Bureau of Statistics. (2016a). The Druze population in Israel - Complication of statistics on the occasion of the Festival of the Prophet Shu'eib.

Central Bureau of Statistics. (2016b). Pupil forecast for the education system, 2017-2921. Report of methodology and findings.

Council of Higher Education Law. (1995). Amendment no. 10.

Dana, N. (1998). The Druze. Ramat Gan, Israel: Bar Ilan University.

Davidovitch, N. (2015). Education and employment, an inseparable couple? On education as an introduction to

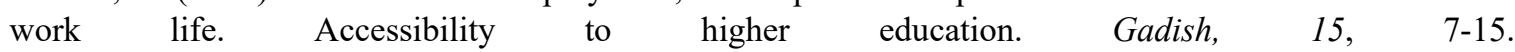
http://meyda.education.gov.il/files/AdultEducation/gadish/nitza_davidovitz.pdf

Education at a Glance. (2007). OECD Indicators - 2007 Edition.

Falah, S. (1991). Higher education among the Druze in Israel. Maalot, 20(B), 126-135.

Falah, S. (2000). The Druze in the Middle East. Tel Aviv: Ministry of Defense.

Faraj, R. S. (2002). The ties between the Druze and the Jews before the establishment of the State of Israel (1948). Yanhuah.

Gabizon, R. (1998). A Jewish and democratic state? In E. Rekhess (Ed.), Arabs in Israeli Politics: Dilemmas of identity (pp. 125-137). Tel Aviv: Moshe Dayan Center for Middle Eastern and African Studies, Tel Aviv University.

Klein, C. (1987). Israel as a nation-state and the problem of the Arab minority: In search of a status (mimeographed). Tel Aviv: International Center for Peace in the Middle East.

Orr Committee. (2003). The Orr committee report. Retrieved from http://uri.mitkadem.co.il/vaadat-or/vaadat-or-part6.html

Peled, A. (1976). Education in Israel in the 1980s. Proposal for a program submitted to the Minister of Education and Culture (Vol. 1). Jerusalem: Ministry of Education.

Peled, A. (2006). The 100 concept program: A Rawlsian critique. Adala, 27. Retrieved from http://www.adalah.org/newsletter/heb/jul-aug06/ar1.pdf

Rabin, Y. (2002). The right to education. Srigim - leon: Nevo Publishers Ltd.

Saban, A. (2002). The collective rights of the Arab-Palestinian minority: What is, what isn't, and what is taboo. Iyunei Mishpat, 26, 241-243. 
Salah, S. (1989). The history of the Druze. Ramat Gan: Bar Ilan University and the Ministry of Defense.

Scrimin, S., Moscardino, U., \& Natour, M. (2014). Socio-ecological correlates of mental health among ethnic minorities in areas of political conflict: A study of Druze adolescents in Israel. Transcultural Psychiatry, 51(2), 209-227. https://doi.org/10.1177\%2F1363461513520342

Smooha, S. (1999). The status-quo option: Israel as an ethnic democracy - a Jewish democratic state. In S. Osetchky-Lazar, A. Ganem, \& A. Pepe (Eds.), 7 ways - theoretical options for the status of Arabs in Israel (pp. 23-77). Givat Haviv, Israel: Center for a Shared Society.

Smooha, S. (2004). For the sake of balance between a "Jewish" state and a "democratic" state. In S. Hasson \& H. Abu-Asaba (Eds.), Jews and Arabs in Israel facing a changing reality: Problems, trends, scenarios, and recommendations (pp. 29-37). Jerusalem: Floersheimer Institute for Policy Studies.

State Archive. (1.1.84-30.6.85). File GAL-18646/4 Education system policy - Druze education. File: ISA-education-education-000h44p. Retrieved from https://www.archives.gov.il/archives/\#/Archive/ 0b071706800171a7/File/0b071706806654b26

State Comptroller and Ombudsman. (2002). Annual report 51B. Jerusalem: Keter. Jerusalem.

Viner Levy, N. (2004). "I am a bird but I can't yet fly": The identity of the first Druze women who turned to higher education (Doctoral dissertation, Hebrew University of Jerusalem).

Weisbleu, A. (2016). The Druze education system and Druze integration in higher education - Key Figures. Jerusalem: Knesset Research and Information Center.

\section{Note}

Note 1. The decline in the number of Druze pupils in Israel is attributed to the sharp decline in the fertility rate of Druze women from an average of 9.7 in 1964, 4.1 in 1990, 3.1 in 2000, and 2.5 in 2010.

\section{Copyrights}

Copyright for this article is retained by the author(s), with first publication rights granted to the journal.

This is an open-access article distributed under the terms and conditions of the Creative Commons Attribution license (http://creativecommons.org/licenses/by/4.0/). 